\title{
There is No Need for the Terms Polysemy and Homonymy in Lexicography
}

Henning Bergenholtz, Centre for Lexicography, Aarhus University, Denmark(hb@asb.dk) and Department of Afrikaans and Dutch, Stellenbosch University, Stellenbosch, South Africa

and

Heidi Agerbo, Centre for Lexicography, Aarhus University, Denmark(heap@asb.dk)

\begin{abstract}
This paper describes a radically different approach to polysemy and homonymy from the ones normally presented in linguistic and lexicographic literature on this topic. Our main criticism of the traditional approaches lies in their use of the term "word": If a word is defined as a linguistic sign, it means that it only has one expression and one meaning, and this entails that defining polysemy and homonymy as phenomena where one word has two or more meanings is not only problematic - it is impossible. For this reason, we argue that polysemy and homonymy do not exist. Furthermore, we claim that they are not even necessary concepts in lexicography as each lexeme could be represented by a lemma in an information tool. However, by changing the definitions of polysemy and homonymy to phenomena where an expression has two or more meanings, thereby focusing on the expression, it is possible to retain the terms. We propose that the best way to apply and also distinguish between polysemy and homonymy in an information tool would be to present the same expressions with different meanings as well as different grammars as homonyms, while expressions with different meanings but the same grammar are presented as polysems.
\end{abstract}

Keywords: MEANING, POLYSEMY, HOMONYMY, LEMMA, HEADWORD, LEXICAL WORD, GRAMMATICAL WORD, ORTHOGRAPHICAL WORD, TEXT WORD

Opsomming: Daar is geen behoefte aan die terme "polisemie" en "homonimie" in die leksikografie nie. Hierdie artikel bied 'n radikaal ander benadering tot polisemie en homonimie vergeleke met die benaderings oor hierdie onderwerp wat tipies in taalkundige en leksikografiese literatuur te vinde is. Ons belangrikste kritiek op die tradisionele benaderings lê in die gebruik van die term "woord". As ' $n$ woord gedefinieer word as ' $n$ linguistiese teken beteken dit dat dit net een uitdrukkingsvorm en een betekenis het. Dit impliseer dat dit nie problematies is nie maar onmoontlik om polisemie en homonimie te omskryf as verskynsels waar een word twee of meer betekenisse het. Om hierdie rede voer ons aan dat polisemie en homonimie nie bestaan nie. Daarbenewens stel ons dit dat hulle nie eers nodige begrippe in die leksikografie is nie aangesien elke lekseem deur 'n lemma in 'n inligtingswerktuig verteenwoordig kan word. Deur die definisies van polisemie en homonimie te verander tot verskynsels waar 'n uitdrukking twee of meer betekenisse het, is die fokus op die uitdrukking en is dit moontlik om die terme te behou. Ons stel voor 
dat die beste manier om tussen polisemie en homonimie te onderskei en om dit toe te pas in 'n inligtingswerktuig is om dieselfde uitdrukkings wat verskillende betekenisse en verskillende grammatiese waardes het as homonieme aan te bied terwyl uitdrukkings met verskillende betekenisse maar dieselfde grammatiese waarde as poliseme aan te bied.

Sleutelwoorde: BETEKENIS, GRAMMATIESE WOORD, HOMONIMIE, LEKSIKALE WOORD, LEMMA, ORTOGRAFIESE WOORD, POLISEMIE, TEKSWOORD, TREFWOORD

\section{The tradition in linguistics and lexicography}

In traditional linguistic and lexicographic literature, polysemy and homonymy are gathered under the umbrella term ambiguity. The common and shared definition of polysemy is that it is the phenomenon where a single word has two or more related meanings, and the common and shared definition of homonymy is the phenomenon where a word has two or more unrelated meanings. Another typical definition of homonymy is that it is the phenomenon where two or more words that are identical in form have different meanings. There are two main problems with these definitions.

The first one is the foundation of the distinction made between polysemy and homonymy. The typical one, as already mentioned, is the semantic criterion. Based on this criterion, word meanings are analysed as either semantically related or unrelated, which is highly based on individual intuition. Some typical examples of this kind of principle are discussed in Geeraerts (2013: 492494) for primer and fresh, though he does not use the term "homonym", only the terms "polysem", "sense" and "subsense":

Lemma 1 with expression $1+$ meaning $A$

Lemma 2 with expression 2 + the common meaning element a as homonym I

polysem 1 for meaning $B$

polysem 2 for meaning $C$

polysem 3 for meaning $\mathrm{D}$

Lemma 3 with expression 2 + the common meaning element $b$ as homonym II

polysem 1 for meaning $\mathrm{E}$

polysem 2 for meaning $\mathrm{F}$

polysem 3 for meaning $G$

Model (1): A polysem-homonym model based on semantic distinctions

If a word is homonymous, the homonyms are presented as individual dictionary entries, but if it is polysemous, the polysems are grouped under the same entry word. Establishing whether two meanings of a word are homonymous or polysemous (or even subpolysemous), is, however, a task that will normally 
result in different solutions from one lexicographer to the next.

A different type of distinction between homonymy and polysemy is presented from the etymological approach, which looks at meaning from a diachronic perspective, in which two meanings are unrelated if it is impossible to trace any historical connection between them. This approach, however, is useless from a synchronic perspective, because even though two senses of a word are synchronically unrelated, they may be diachronically related.

A third approach is the formal approach with which polysemy and homonymy are established based on formal criteria. This means that words that are orthographically similar but have different inflectional paradigms (also within the same part of speech) are defined as homonyms, whereas orthographically similar words belonging to the same part of speech and with the same inflectional paradigm are defined as polysems.

These three as well as other approaches applied in the work on polysemy and homonymy overlook one important thing that leads to the second critical point and major problem in the literature on polysemy and homonymy: The use of the term "word".

\section{The linguistic sign and types of words}

In the structuralist tradition of Saussure and Hjelmslev, one of the main notions is the linguistic sign, which is defined as containing two parts: the expression and the content, with a mutual relationship between the two. Hjelmslev calls this relationship solidarity:

Saaledes bestaar der ogsaa solidaritet mellem tegnfunktionen og dens to funktiver: udtryk og indhold. Der vil aldrig foreligge en tegnfunktion uden at begge disse funktiver samtidig er til stede. (Hjelmslev 1943: 45)

[Eng.: Thus, solidarity also exists between the sign and its two functives: expression and content. There will never be a sign without the mutual presence of both functives.]

When linguists and lexicographers talk about polysemy, they typically say something along the line of polysemy - and also homonymy - is when one word has more than one meaning. This is a very superficial definition, but that is not the main problem. The problem is the use of "word". Based on the quote by Hjelmslev, a "word" cannot be a linguistic sign because according to the definition of the sign, we have two different linguistic signs when there are two different meanings:

for expression 1 with solidarity to content $\mathrm{A}$, we have one sign

for expression 1 with solidarity to content $B$, we have another sign

The problem that must be solved in order to understand what is meant by polysemy and homonymy is to find out what we mean when we use the term "word". 
A word is not a word, or, more specifically, we have different kinds of words (Bergenholtz and Mugdan 1979: 12-29 and 116-125) which are: orthographical word, text word, grammatical word, lexical word (lexeme) and dictionary word (lemma). These word types are all relevant in lexicography:

An orthographical word is defined as a sequence of letters between blanks and sentence signs (like comma). Orthographical words are also used as search strings in e-dictionaries. But an orthographical word is not a linguistic sign because one and the same orthographical word can be related to different contents.

A text word is a concrete word in a text with a specific spelling, meaning, grammar etc. If - especially in the case of a reception problem - a potential dictionary user comes across a text word in the text he is reading, he will write an orthographical word corresponding to the expression of the text word in the search field or look for it in the lemma list. A text word is a linguistic sign and as such the main object for dictionaries, but it is not used, with the exception of author's dictionaries, directly in the production and the use of dictionaries because text words are unique in the specific texts in which they occur, and the search in dictionaries is conducted using an orthographic word.

A grammatical word is an expression with at least one nucleus morpheme and for adverbs, verbs and nouns also at least one grammatical morpheme (Bergenholtz and Mugdan 1979: 118-125). A grammatical word belongs to a certain inflexion paradigm (for words without inflexion, this paradigm consists of only one grammatical word). All or some of the grammatical words belonging to one lexeme are listed in many dictionaries after the lemma. It is possible to search for them in many e-dictionaries if searching with a search string equal to this grammatical word, i.e. not only the typical lemma form. A grammatical word is not a linguistic sign because one and the same grammatical word can belong to more than one lexeme.

A lexical word or a lexeme is the abstraction for an amount of grammatical words belonging to the same stem and the same inflexion paradigm. In order to show the abstract status of a lexical word, Bergenholtz and Mugdan (1979) gives lexical and grammatical words different notions: $\mathrm{BUCH}_{\text {Substantiv }}$ \{Buch, Buch, Buches, Buch, Bücher, Bücher, Bücher, Büchern\}. A lexical word is a linguistic sign, and different stems result in different lexical words, hence we also define a stem as a linguistic sign with an expression and a meaning. Stems include all alloforms, as for Buch- and Büch-, but the main point is that we do not have alloforms for the content. If we have different stem meanings, then we have different linguistic signs. For instance, in Bergenholtz and Agerbo (2014) we show that the stem pigtail is connected to at least six different lexical words with six very different meanings.

A dictionary word, headword or lemma is the abstraction for an amount of grammatical words, but it is not the same as a lexical word, because, contrary to lexical words, different stem meanings do not result in different headwords. In paper dictionaries, a lemma is normally shown as the expression of 
one and only one of the grammatical words belonging to an inflexion paradigm with the same stem. In dictionary articles in e-dictionaries, the user will often only see the expression for one of the grammatical words in the inflexion paradigm, but the search algorithm can search in the whole paradigm.

In the lexicographical tradition, described in this article as polysemhomonym-models (1) and (3), a lemma is not a linguistic sign because a lemma can represent different lexical words (sometimes it represents only one lexeme, in other cases it represents several lexemes). Hence, there is no solidarity between one expression and one content. Only in the radical solution, which has been described below as model (2), where we discard polysemy and homonymy and instead connect each lexical word to its own lemma, the lemma could be defined as a linguistic sign.

\section{Polysemy and homonymy do not exist}

According to the argument presented in Chapter 2, we cannot speak about polysemy and homonymy if we relate these terms to the linguistic sign. However, in lexicography we can do well without these terms. The solution to get around them would be to have one lemma (one dictionary word) for each lexeme and provide the grammar items for each lemma. This means that we have one and only one lexeme in each dictionary article. This could easily be done in e-dictionaries, though in printed dictionaries this solution would require too much space for at least one-volume dictionaries.

Lemma 1 with expression $1+$ grammar $Z+$ meaning $A$

Lemma 2 with expression $2+$ grammar $Z+$ meaning $B$

Lemma 3 with expression $2+$ grammar $Z+$ meaning $C$

Lemma 4 with expression $2+$ grammar $Z+$ meaning $D$

Lemma 5 with expression $2+$ grammar $Z+$ meaning $E$

Lemma 6 with expression $2+$ grammar $Y+$ meaning $F$

Lemma 7 with expression $2+$ grammar $Y+$ meaning $G$

Model (2): A model without polysemy and homonymy

In the case of lemma 1 with expression 1 , which is related to only meaning $\mathrm{A}$ and grammar Z, of course, we cannot talk about polysemy or homonymy because there is only one meaning. But neither can we call the lemma a linguistic sign. Imagine that we have expression 2 that is related to more than one meaning; for each lemma, we find partly the same, partly not the same grammar, but in each dictionary article, there are different meanings. In this case, the lemma is not a linguistic sign. Though expression 1 is connected to only one meaning and one grammar, it does not make sense to call the lemma a linguistic sign because how, then, would we distinguish between lemmas that are linguistic signs and lemmas that are not? 


\section{Polysemy and homonymy do exist}

In Chapter 3 and in Bergenholtz and Agerbo (2014), we argue that polysemy does not exist and that we do not consider polysemy a useful term in lexicography. However, we could also move in the opposite direction and argue that both polysemy and homonymy actually do exist. However, this requires a different definition of the terms. If we focus on the expression of the linguistic sign, i.e. if polysemy is related to the expression of the linguistic sign instead of the linguistic sign with one expression and one meaning, it is possible to argue in favour of both polysemy and homonymy. With this definition, it is possible to say that polysemy is the phenomenon where the same expression (not word!) is connected to several meanings. Hence, an expression is polysemous if it is connected to more than one meaning. If there are two or more meanings and a distinction appears in the part of speech or the inflection paradigm within the same part of speech, the expression is not polysemous, but homonymous.

This approach is contrary to the typical one in linguistics and lexicography, though dictionaries such as The Danish Internet Dictionary (2014) and Wahrig (1986) already apply this approach to polysemy and homonymy. Of course, this entails that some of the homonymous meanings are semantically closer connected than others, but this approach instead has the advantage that polysemy and homonymy may be treated systematically instead of intuitively. Whether the homonymous meanings or the polysemous meanings connected to an expression are close or not may be a relevant linguistic problem to explore, but for the dictionary user this is unimportant, at least in a reception situation. It could be relevant in a cognitive dictionary, if the user is interested in learning more about the expression.

Using the same distribution of expressions and meanings as in model (2), we now only have 3 lemmas instead of 7:

Lemma 1 with expression $1+$ grammar $Z+$ meaning $A$

Lemma 2 with expression $2+$ grammar $Z$ as homonym I polysem 1 for meaning $B$ polysem 2 for meaning $C$ polysem 3 for meaning D polysem 4 for meaning E

Lemma 3 with expression $2+$ grammar $Y$ as homonym II polysem 1 for meaning $F$ polysem 2 for meaning $\mathrm{G}$

Model (3): A polysem-homonym model based on grammatical distinctions

\section{Application of the three models}

With model (1), we can use a diachronic argumentation intended for a cogni- 
tive dictionary to show that a certain meaning is the original one (the earliest one) and that it forms the basis for later derived meanings of a certain orthographic word. As an example, we can take the lemma pigtail, for which the meaning 'the hindmost part of a pig' corresponds to the earliest use of the word (see Bergenholtz and Agerbo 2014). According to model (1), the six meanings expressed by the lemma pigtail are not homonyms, but polysems:

1. the small, curly body part on the hindmost part of a pig

2. the fleshy tail from a pig used for cooking, e.g. in soups, or prepared as a snack for dogs

3. a length of hair that is tied at the back of the head or at each side of the head, sometimes in a braid; mainly worn by women

4. a waist-long braided ponytail made by braiding the hair at the back of the neck, often also combined with the hair on the front of the head being shaved off, which men in ancient China were demanded to wear as a symbol of submission and obedience

5. item of artificial material resembling braided human hair, which is attached to the back of a Chinese hat and often worn as part of a costume imitating a Chinese man from ancient China

6. one, two or several pom-poms or strings of yarn or other fabric attached to a knitted hat, which often resemble a braid of hair or the tail of a pig

Instead of this presentation, model (1) could be based on a synchronic description of the use of this orthographic word. Applying model (1), this would result in three homonyms each with two polysems. This presentation would also be suitable for a dictionary with cognitive functions:

Homonym I 'the hindmost part of a pig'

1. the small, curly body part on the hindmost part of a pig

2. the fleshy tail from a pig used for cooking, e.g. in soups, or prepared as a snack for dogs

Homonym II 'natural or artificial hair'

1. a length of hair that is tied at the back of the head or at each side of the head, sometimes in a braid; mainly worn by women

2. a waist-long braided ponytail made by braiding the hair at the back of the neck, often also combined with the hair on the front of the head being shaved off, which men in ancient China were demanded to wear as a symbol of submission and obedience

Homonym III 'hair-like decoration attached to a hat'

1. item of artificial material resembling braided human hair, which is attached to the back of a Chinese hat and often worn as part of a costume imitating a Chinese man from ancient China

2. one, two or several pom-poms or strings of yarn or other fabric attached to a knitted hat, which often resemble a braid of hair or the tail of a pig 
For communicative functions, either model (2) or (3) would be the most suitable one as it will always be the specific use of a word that forms the point of departure in case of a reception problem or a text production problem. First and foremost, the user needs to know what the word means in a specific context (reception) or whether it is possible to use a certain word with the meaning the user wishes to express (production). The only difference between the outcomes of models (2) and (3) for this example is that model (3) results in one lemma with one grammatical description, whereas model (2) results in six different lemmas with each their grammatical description. The solutions based on models (1) and (3) are identical for pigtail as for this lemma there are no grammatical distinctions between the different uses of the word. Had a difference in the grammar been the case, model (1) would still be without homonymy, but model (3) would include homonymy.

\section{Which model can be recommended for modern lexicography?}

The suggestions provided above apply both to monolingual and bilingual dictionaries; there are no significant differences. This is also the case when a bilingual dictionary contains no definitions because equivalents are always selected based on the definitions that would have been selected in a bilingual dictionary with definitions. In many of the dictionaries that we have helped produce, e.g. The Danish Internet Dictionary (2014) or The Spanish Accounting Dictionary (2014), we have applied model (3). This is a clear and precise model, see also Tarp (2008). With this model, contrary to model (1), all lexicographers will make the same labelling of senses as either homonymous or polysemous. Similarly, the principles for model (3) can easily be explained to the dictionary users. We do acknowledge, however, that even though it will be fairly easy for users to understand that different parts of speech result in different grammars, it may be difficult for them to understand the difference between two inflectional paradigms within the same part of speech. The clearest and simplest model is therefore model (2). This one is easier for lexicographers to apply in the production of dictionary articles, and it would also be easier to explain to the users how they can find the pieces of information they are looking for. Neither model (2) nor (3) is connected to any theoretical contradictions, which is the major problem for model (1). What speaks in favour of model (3) is first and foremost that this one is closer to the solution that dictionary users are familiar with.

\section{References}

Bergenholtz, H. and H. Agerbo. 2014. Meaning Identification and Meaning Selection for General Language Monolingual Dictionaries. Hermes. Journal of Language and Communication in Business 52: 125-139.

Bergenholtz, H. and J. Mugdan. 1979. Einführung in die Morphologie. Stuttgart: Kohlhammer. 
Geeraerts, D. 2013. The Treatment of Meaning in Dictionaries and Prototype Theory. Gouws, R.H., U. Heid, W. Schweickard and H.E. Wiegand (Eds.). 2013. Dictionaries. An International Encyclopedia of Lexicography. Supplementary Volume: Recent Developments with Special Focus on Computational Lexicography: 487-495 Berlin: Mouton de Gruyter.

Hjelmslev, L. 1943. Omkring sprogteoriens grundlæggelse. Festskrift udgivet af Københavns Universitet $i$ anledning af Universitetets Aarsfest, November 1943: 1-113. Copenhagen: Bianco Lunos Bogtrykkeri.

Tarp, S. 2008. Lexicography and the Linguistic Concepts of Homonymy and Polysemy. Lexicographica 17: 22-39.

The Danish Internet Dictionary. 2014. = H. Bergenholtz in collaboration with Agerbo, H. in cooperation with Bodilsen, A., S.W. Dohrn, J. Esmann, H.R. Gudmann, Chr. Kjølhede, J. Nguyen, M.L.K. Nielsen, H. Thers. Database: Almind, R. and M. Carlsen. Den Danske Netordbog. Odense: Ordbogen.com.

The Spanish Accounting Dictionary. 2014. = Fuertes-Olivera, P.A., H. Bergenholtz, S. Nielsen, P.G. Gómez, M. Niño Amo, Á. de los Ríos Rodicio, Á.S. Ruano, S. Tarp and M. Velasco Sacristán. 2014. Diccionario Español de Contabilidad: Recepción. Base de Datos y Diseño: R. Almind and J.S. Nielsen. Hamburg: Lemma.com.

Wahrig = Wahrig, G. 1986. Deutsches Wörterbuch. Mit einem "Lexikon der deutschen Sprachlehre“. München: Mosaik Verlag. 